\title{
Constipation: A physiological approach
}

\author{
W Grant Thompson MD
}

WG Thompson. Constipation: A physiological approach. Can J Gastroenterol 2000;14(Suppl D):155D-162D. The first step in managing a patient with constipation is to understand the precise nature of the complaint. Is the onset recent? What are the frequency and form of the stools, and how much effort is required to defecate? Is constipation steady or alternating as in irritable bowel syndrome? Are there structural, metabolic or pharmacological confounders? Is the patient depressed? Has dietary fibre been tried at a sufficient dose? What are the patient's understanding and beliefs about the symptoms? Has there been sufficient and appropriate investigation? Armed with the answers to these questions, physicians can help most patients through lifestyle, dietary and pharmacological adjustments, along with supplementary fibre. Some patients may require regular doses of an osmotic laxative. Those few that fail these measures should have their transit time estimated while on a high fibre diet; if it is normal, further testing is unlikely to help. The above efforts should be re-emphasized, and reassurance should be offered. Some patients may require a psychological assessment. If transit time is prolonged and the patient may benefit from surgery for colonic inertia or biofeedback for anismus, then colon and anorectal function should be assessed. The decision to perform further tests should be made carefully, and unrealistic expectations should be discouraged. Before surgery is offered, the patient should have the benefit of receiving an expert opinion. Biofeedback helps some patients with isolated anorectal dysfunction.

Key Words: Anorectal function; Colon; Colon physiology; Constipation; Stools; Transit time

\section{Constipation : approche physiologique}

RÉSUMÉ : La première étape à franchir dans le traitement de la constipation est de circonscrire la nature des symptômes. Sont-ils d'apparition récente? Quelles sont la fréquence et la forme des selles, et quelle intensité d'effort la défécation exige-t-elle? La constipation est-elle permanente ou épisodique comme dans le cas du syndrome du côlon irritable? Y a-t-il des facteurs confusionnels liés aux structures, au métabolisme ou à la prise de médicaments? Le patient est-il déprimé? A-t-il essayé un régime alimentaire suffisamment riche en fibres alimentaires? Comment le patient interprète-t-il ses symptômes? Les symptômes ont-ils fait l'objet d'une évaluation appropriée? Munis des réponses à ces questions, les médecins sont en mesure d'aider la plupart des patients par des interventions touchant le mode de vie, le régime alimentaire et la prise de médicaments; à cela s'ajoute un complément de fibres. Certains patients peuvent avoir besoin régulièrement de laxatifs osmotiques. Dans les rares cas d'échec du traitement, le temps de transit devrait être évalué pendant que les patients suivent un régime riche en fibres; si le temps est normal, il est peu probable que d'autres examens puissent apporter un soulagement quelconque. Il faudrait insister de nouveau sur les interventions précédentes et rassurer les patients. Certains d'entre eux devront être soumis à une évaluation psychologique. Si le temps de transit est prolongé et si une intervention chirurgicale pour inertie du côlon ou la rétroaction biologique pour anismus peuvent s'avérer bénéfiques, il faudrait procéder à une évaluation du fonctionnement du côlon, du rectum et de l'anus. La décision de poursuivre les examens devrait être prise en connaissance de cause, et il faudrait tempérer les attentes irréalistes. Le patient devrait avoir droit à l'avis d'un deuxième médecin avant qu'on lui propose l'intervention chirurgicale. La rétroaction biologique peut aider parfois les patients souffrant de dysfonctionnement ano-rectal occasionnel.
$\mathrm{C}$ onstipation is a very common complaint in primary care and gastroenterology practice. It is said to be present in $1 \%$ to $8 \%$ of the population (1-5), but these figures are very much subject to how one defines constipation. Indeed, Probert et al (2) found that constipation was present in about $60(8 \%)$ of 731 randomly selected women, defined by patient complaint, expert opinion (Rome criteria, Table 1)
$(6,7)$ or stool form as a surrogate measure of transit time (vide infra). However, these definitions each selected a different 60 people. Only 17 women were constipated according to all three definitions. These data show the importance of determining in detail what the patient means by 'constipation' and the need to interpret his or her symptoms in physiological terms. In this paper, stool and the colorectal

This review was prepared from a presentation made at the Canadian Association of Gastroenterology Meeting, Banff, Alberta, March 1 to 8, 1998. Division of Gastroenterology, University of Ottawa, Ottawa, Ontario

Correspondence: Dr W Grant Thompson, Emeritus Professor of Medicine, University of Ottawa, 7 Nesbitt Street, Ottawa, Ontario, K2H 8C4.

Telephone 613-828-7300, fax 613-828-7300, e-mail wgthompson@home.com 
TABLE 1 Diagnostic criteria for functional constipation*

Two or more of the following for at least three months

- Straining at defecation at least one-quarter of the time

- Lumpy and/or hard stools at least one-quarter of the time

- Sensation of incomplete evacuation at least one-quarter of the time

- Two or fewer bowel movements per week

Abdominal pain is not required, loose stools should not be present, and there must be insufficient criteria for irritable bowel syndrome. Absence of structural, metabolic and pharmacological causes of constipation is implied. These criteria may not apply when the patient is taking laxatives. Data from references 6 and 7. *Rome II criteria published in 1999 (see Appendix 1)

physiology responsible for delivering it are discussed. Armed with this information, a practical algorithm can be constructed for primary care physicians and specialists who care for patients with constipation.

\section{THE STOOL}

Constipation cannot be understood without knowledge of the nature of stool. While the frequency of defecation is an important characteristic to consider, stool form (consistency) and the effort needed to expel the stool are also important. In physiological terms, constipation is best measured by colon transit time, but it, in turn, is dependent on stool size and the motor prowess of the colon and anorectum.

Determinants of stool size: Stool is the residue left over from the absorption of ingesta in the small intestine, and consists mainly of bacteria, water and gas. Unabsorbed material is largely carbohydrate that is resistant to small intestinal enzymes and subject to degradation by colon bacteria (8-10). It seems that colon bacteria is acquired in infancy. The bacteria remain for a lifetime and have a composition as unique to the individual as fingerprints. These bacteria determine the extent and nature of the degradation of small bowel products and, therefore, must play an important role in determining stool size and composition, colon gas production and defecation. Little is known about this process. The colon remains a dark continent of clinical research, but the following facts are notable.

While all human colons produce varying amounts of hydrogen and carbon dioxide (11), only one-third of colons produce methane - a result of the presence of Methanobacter species (12) and dietary sulphate (13). These gases are important determinants of stool volume and are a more likely cause of floating stools than fat content. Dietary bulk that escapes bacterial degradation has water-holding properties that help to determine stool size (14-16) and transit time $(17,18)$. Particle size seems important: coarse bran, by resisting bacterial degradation, has a greater effect on stool weight and transit than fine bran (14).

Gastrointestinal transit time is related to the characteristics of the stool. A large stool traverses the colon faster, and those on a high fibre diet have faster gut transits and less constipation (17). Slow transit increases the time available for colonic water absorption, bacterial degradation and gas formation, thus fundamentally altering the stool form.
TABLE 2

The Bristol stool form scale

\begin{tabular}{ll}
\hline Type & Description \\
\hline 1 & Separate, hard lumps like nuts (difficult to pass) \\
2 & Sausage-shaped but lumpy \\
3 & Like a sausage but with cracks on surface \\
4 & Like a sausage or snake; smooth and soft \\
5 & Soft pieces with clear-cut edges (easy to pass) \\
6 & Fluffy pieces with ragged edges; a mushy stool \\
7 & Watery; no solid pieces; entirely liquid \\
\hline
\end{tabular}

Data from reference 20

Even psychological and personality factors seem important. Extroverted, outgoing people have larger stools than those who are introverted (16). In contrast, stool size may be an important factor in the constipation that is seen so often in the depressed. These variables are important for the understanding of constipation and may offer clues for effective management.

Stool form: When considering a complaint of constipation (or diarrhea), stool form or consistency is more important than frequency. Many misperceptions about constipation can be resolved if a detailed description of the stools is obtained. Patients may claim that the frequent production of pellety stools is diarrhea, even though such stools are associated with prolonged colonic transit (19-21). This has been termed 'pseudodiarrhea' (20). Indeed, stool form can serve as a surrogate marker of gut transit (Table 2) (18-20) and, therefore, is a reliable indicator of constipation.

The importance of large stools: Stool size is important in the recognition, investigation and treatment of constipation. The classic 1972 study of stool weight and transit by Burkitt et al (17) found that East Africans had stools five times as heavy that moved twice as quickly through the gut as subjects in the Western world. He reasoned that the differences were attributable to the very high fibre diet of native Africans compared with the refined, packaged diet of Europeans. This inverse relationship of stool weight and transit time has been confirmed experimentally (8), as has the ability of increased dietary fibre to increase stool weight and the speed of gut transit $(8,22,23)$. This ability of fibre to increase stool bulk is incompletely understood. Fibre has some water-holding properties, but the products of digestion, gas and quickly absorbed short-chain fatty acids may also be important $(15,24)$.

Using plastic stools, Bannister et al (25) showed that larger stools are easier for the anorectum to expel than small stools. This is the scientific basis for the dietary treatment of constipation. Clinical data are available and are presented in further sections $(22,23)$.

\section{PHYSIOLOGICAL CONSIDERATIONS}

Clinically, constipation is defined as a group of functional disorders that present as persistent, difficult, infrequent or seemingly incomplete defecation $(26,27)$. However, constipation is likely best defined physiologically as delayed transit 

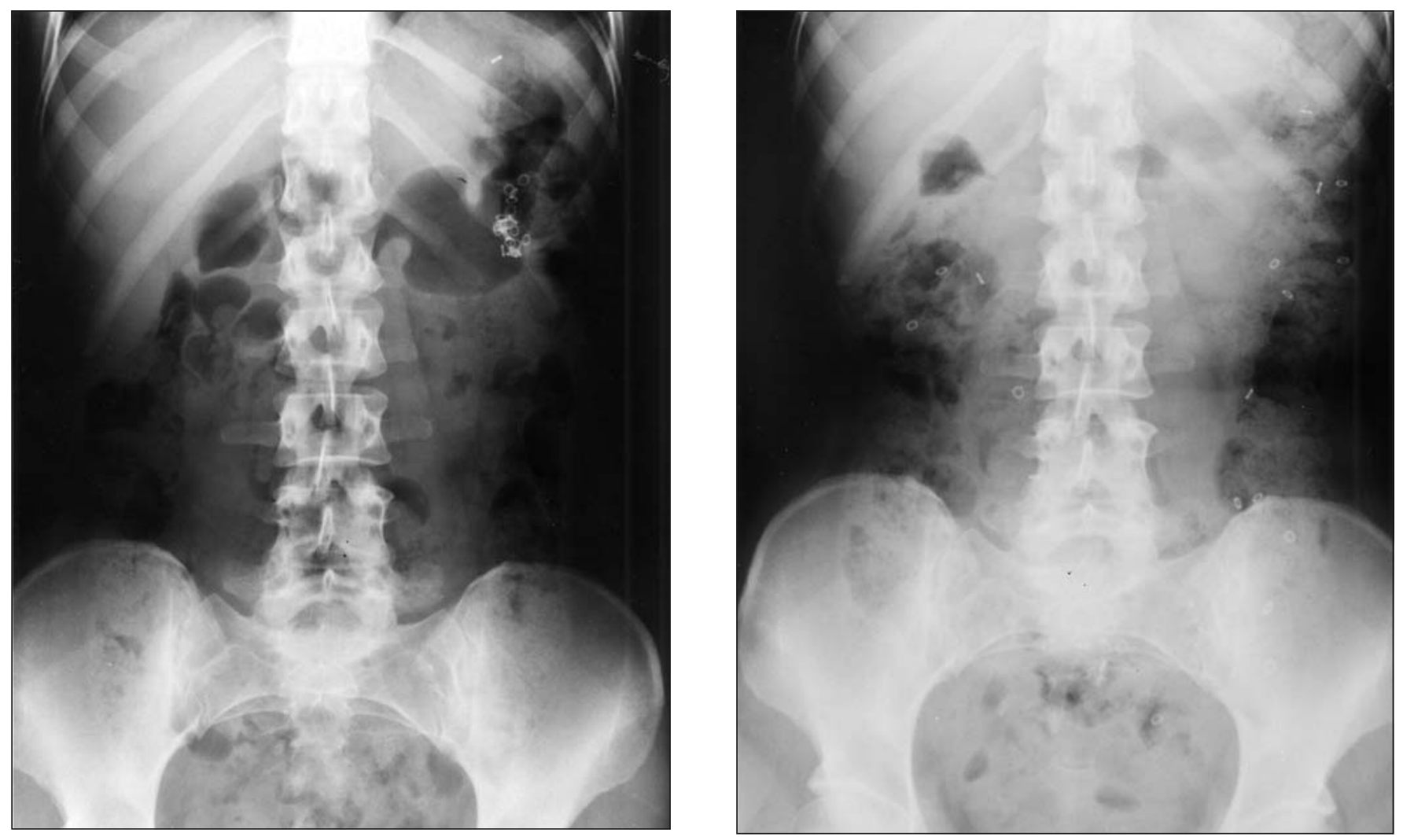

Figure 1) Whole-gut transit. Left Day 0. Twenty-five radiopaque markers have been swallowed and are in the stomach. Right Day 13. The markers have still not passed through the colon; the patient has a very marked impairment of transit. Note the stool-filled colon. This test should be performed while the subject is on a high fibre diet

through the gut. Thus, transit time is an important consideration, and its measurement is an important first step if the sophisticated investigation of recalcitrant constipation is considered. Such testing is directed at the detection of a defect in colon transit or anorectal function. These defects are uncommon, are difficult to identify positively and are often very complicated to treat. Their investigation is justified only in severely affected patients with prolonged transit time who are likely to benefit from surgery or biofeedback. First, normal defecation is considered.

Optimal conditions for defecation: Physiological information is available to allow physicians to advise patients about how to improve their likelihood of achieving normal defecation. The 'gastrocolonic response' is the normal urge to defecate after a meal (28). It is hormonally and cholinergically $(28,29)$ mediated; it warns a person to be positioned at the toilet when it occurs. Usually, this response is best experienced after breakfast. Fat (28) and caffeine seem to heighten the colonic response. Thus, a routine that includes a visit to the bathroom after a hearty breakfast of bacon and eggs with coffee may optimize natural responses.

In Western communities, little thought is given to the position of defecation; we have become adapted to Crapper's water closet (30). Our ancestors and most of the world today assume the squat position to defecate $(31,32)$. Physiologists point out that this anatomical position optimizes the attitude of the anorectum and provides the best trajec- tory for stool. It seems unlikely that patients will reassume the squat, and modern bathroom designers do not have such an eventuality in mind. Nevertheless, this position may be mimicked by placing a footstool in front of the toilet, thus elevating the subject's thighs and repositioning the pelvis.

Perhaps the greatest physiological requirement for recalcitrant defecation is time. Precivilized man simply defecated when the urge overtook him. Through centuries of civilization, social restrictions on the time and place of defecation have been devised. Modern society does not build defecation into its daytimers, and the act is often denied or rushed. The constipated individual needs to unlearn this unhealthy byproduct of 'evolution'.

Transit time: While colonic transit seems a simple concept, it is not. Unlike time trials in the Grand Prix, one cannot simply swallow a marker and record its arrival at the anus with a stopwatch. A marker must reflect the properties of stool. Liquids, large volumes and heavy materials travel faster through the gut. Also, transit is dependent on the consistency $(14)$ and specific gravity $(9,10)$ of the intestinal contents. Does one measure passage by the beginning point, the end point or the halfway point of a stool? Radiopaque markers have been used with the presumption that they will evenly distribute themselves within the stool and pass along with the stool (Figure 1). But when different shaped markers are given for three consecutive days, some of the shapes given 


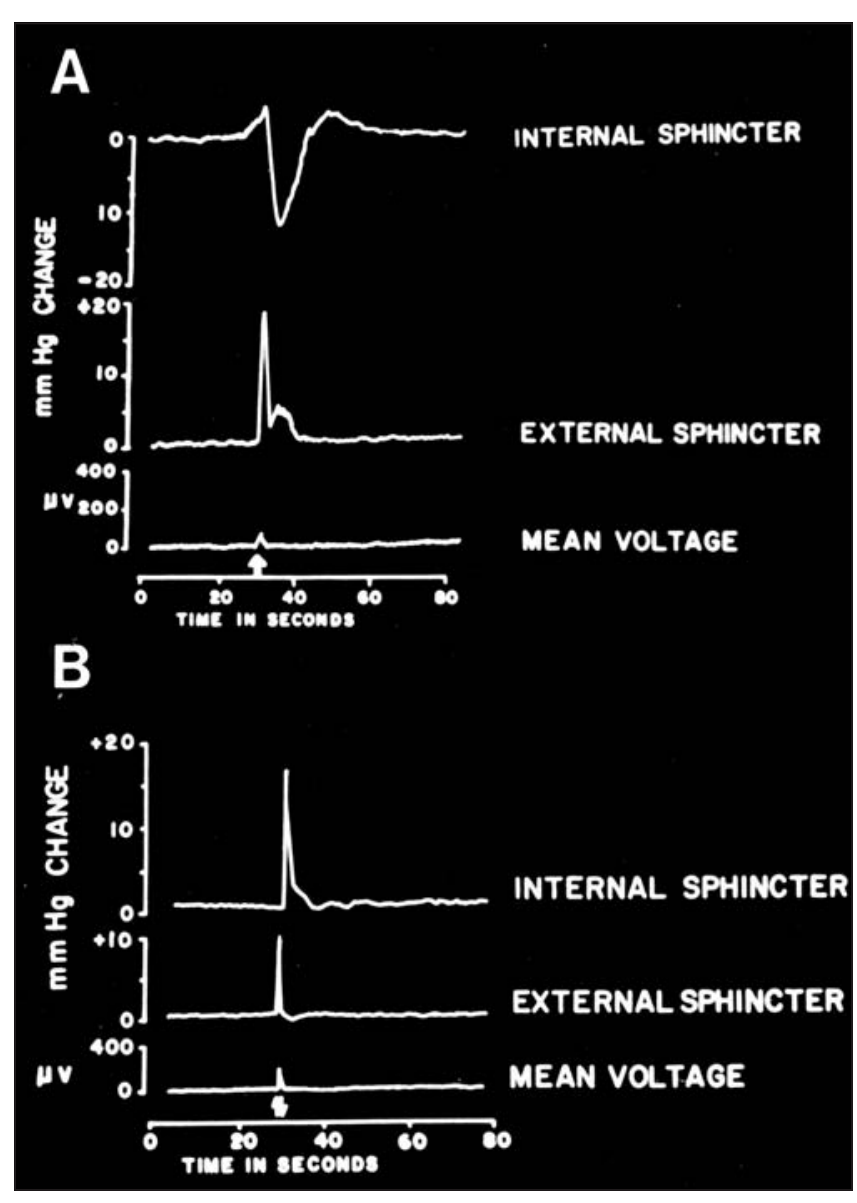

Figure 2) Anorectal manometry measures the internal and external anal sphincter response to balloon distension of the rectum. Arrows indicate the time of balloon distension. A In normal individuals, rectal distension reflexly relaxes the internal sphincter, while the conscious individual, deeming the time for defecation inappropriate, voluntarily tightens the external sphincter. B In Hirschsprung's disease, the denervated internal sphincter fails to relax, thus obstructing defecation

on day 3 appear before some given on day 1 . Moreover, markers measure whole-gut, not colonic transit time. One could subtract the oral-cecal time as determined by a hydrogen breath test (33); however, that procedure is cumbersome, and the oral-cecal transit time is negligible. A method of measuring whole gut transit is described below.

Colon motility: Colon inertia may be diagnosed when, despite a high fibre diet, transit is prolonged. Even in specialized centres, these patients may represent only one-third of constipated patients and may include some of those who also have anorectal dysfunction (34). The increased contact time with the mucosa increases water absorption, resulting in lumpy and infrequent stools, straining, and a feeling of incomplete evacuation. Slow transit constipation refers to very slow transit that is poorly responsive to all therapeutic measures $(35,36)$.

Megacolon is recognized by barium enema and should prompt anorectal motility testing to exclude the rare case of Hirschsprung's disease, especially in children (Figure 2) $(37,38)$. The colonic distribution of transit time markers, intracolonic pressure measurements (at least of the rectosigmoid) (39) and radioscintography (40) have all been

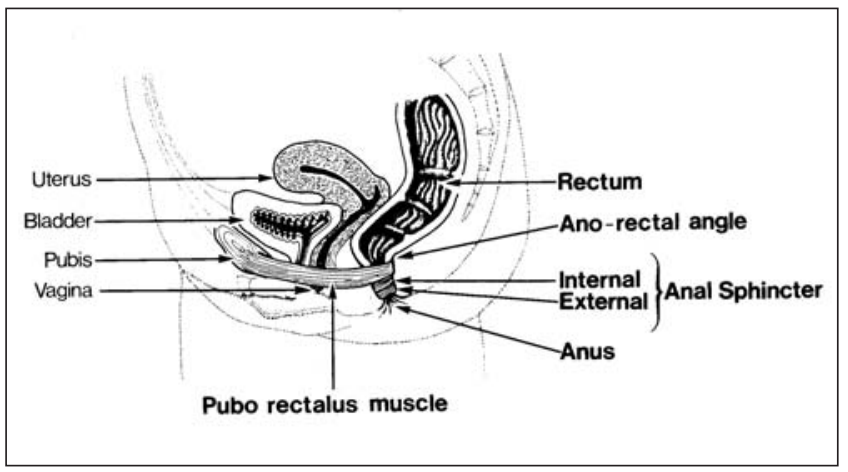

Figure 3) Anorectal anatomy. The striated puborectalis muscle pulls the rectum forward, creating a sharp anorectal angle. This angle should be much less acute during defecation for stool to pass easily. The internal sphincter consists of smooth muscle which contracts involuntarily. Rectal distension causes the internal sphincter to relax and the external sphincter to contract, preventing precipitous defecation (see Figure 2A).

used to measure colon function but are imprecise. Certainly, subtotal colectomy and ileorectal anastomosis should not be contemplated until a generalized motility disturbance has been excluded by esophageal, gastric and small bowel (41) motility tests, and anorectal function is deemed to be normal (vide infra). Certainly the wise physician will avail himself or herself to the best surgical and medical opinion available. Some patients have both constipation and incontinence because of neurological damage and may benefit from an ileostomy.

Anorectal function: Anorectal dysfunction can be suspected in patients with a full rectum that does not empty despite excessive straining. Some patients digitally assist evacuation through the rectum or vagina, or press on their abdomen. When asked to strain, the perineum fails to descend. Unfortunately, the relationship of these symptoms to physiological tests is inexact (42). Some believe that anismus is characterized by the collection of transit time markers at the anorectum. The most definitive abnormality is that seen in Hirschsprung's disease $(37,43,44)$; here, the denervated internal sphincter fails to relax (Figure 2). While this is a rare abnormality in adults, it is important to detect. Surgical remedies are available if the short denervated segment can be demonstrated by biopsy. In anismus, the puborectalis sling fails to relax sufficiently to permit the anorectum to straighten for unimpeded stool passage (Figure 3) (45-48). Defecation is thereby obstructed.

\section{MANAGEMENT OF CONSTIPATION}

Initial workup: An initial history and physical examination should determine the nature and severity of the constipation, the adequacy of treatments so far, and the presence of morbid conditions that may contribute to the symptoms. Thus, the physician should inquire about stool frequency, stool form and the effort required to defecate. Any depression, neuropathy, hypothyroidism, diabetes, drugs (opiates, psychotropics, anticonvulsants, anticholinergics, dopaminergics, calcium channel blockers or bile acid binders) or other possible cause of constipation should be noted. Structural disease should be excluded if suspected. Most patients should have at least a peri- 
anal inspection, digital rectal examination and sigmoidoscopy; any patients older than 45 years or at risk of cancer should also have a barium enema. Complete testing of blood counts and erythrocyte sedimentation rates should be normal procedure. From there, one can embark on the algorithm proposed in Figure 4. However, there is an exception to the algorithm: if there is reason to suspect Hirschsprung's disease, especially in children, one must jump directly to anorectal motility testing.

If no other disease is present, the next step is to ensure that dietary fibre has been tried sufficiently. In primary care and even among patients seeing specialists, most constipation will improve if adequate dietary fibre is given $(49,50)$. The incremental effect of dietary fibre on stool weight is dose-dependent $(8,15,22,23,51)$ and requires a week to reach a steady state (15); this dose effect is weaker in patients with slow-transit constipation (52). Fibre is especially likely to be successful if the stools are fragmented, hard or pellety in nature. Adequate stool bulk should soften and defragment the stools. Further treatments or tests should not be contemplated until the physician is satisfied that the constipation will not improve with some type of dietary fibre.

A true high fibre diet is difficult to achieve. For that reason it is best to introduce fibre supplements. The cheapest and best supplement is coarse wheat bran taken by the tablespoon in increments until softer stools are more easily passed. Some patients require more than six tablespoons per day; these can be taken in yogurt, cereal, soups or applesauce. Once successful, the patient may integrate the bran into the diet. Fruit and vegetables are encouraged, but few can achieve sufficient dietary fibre intake with these alone. For those who cannot tolerate bran or have celiac disease, rice bran, psyllium $(53,54)$ or methyl cellulose (55) can be tried. Adequate doses must be taken as the response is dose-related. Some psyllium packages recommend a dose of a teaspoon, which is often insufficient.

Many patients who are constipated have irritable bowel syndrome (IBS) $(26,27,56)$. A careful examination of an IBS patient's history will reveal an intermittency of constipation, with periods of normal defecation or even diarrhea. While IBS patients sometimes benefit from dietary fibre, they will not benefit from further treatments and testing for constipated patients that are described next.

Elderly patients, especially those who have trouble ingesting bulk, may do well taking an osmotic laxative. Lactulose (57), given nightly in one or two tablespoon doses or more, or a similar dose of milk of magnesia (58), may be useful.

\section{PHYSIOLOGICAL STUDIES}

Measurement of transit time: Before proceeding to further testing or treatment, a transit time study should be performed. A whole-gut transit time test is available for any physician; it is an important determinant of what further action is justified in the severely affected patient who fails to respond to dietary fibre or osmotic laxatives. The markers used for transit time measurement may be purchased in capsules (Sitzmark, USA). Each capsule contains 25 radiopaque markers. It is good practice to complete a scout film after ingestion of the capsule to ensure the arrival of the markers in

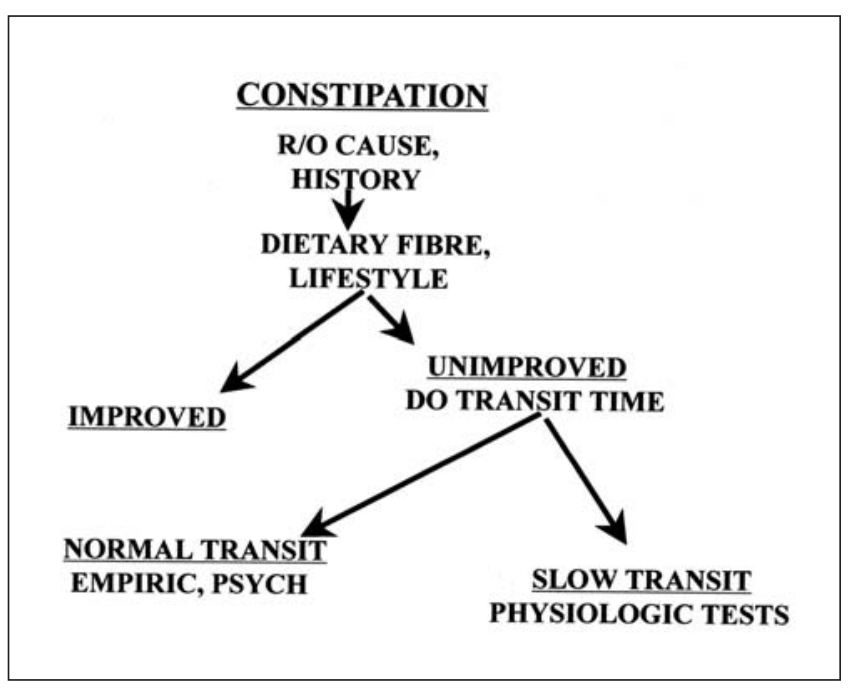

Figure 4) Simplified approach to chronic constipation. Note that irritable bowel syndrome patients have intermittent constipation, abdominal pain and episodes of nonlaxative-induced diarrhea, and are excluded. Each step in this scheme should be carefully considered. Transit time measurement is only indicated after the lifestyle and dietary changes outlined in this article have truly failed. The decision to do physiological tests in patients with prolonged transit depends on the likelihood of benefit. If surgery or biofeedback is out of the question, then such studies are of little use. R/O Rule out

the stomach and to complete further films on day 3 and day 5 . Various formulas have been proposed to establish normal transit through $\mathrm{x}$-ray examination of the abdomen or through examination of each stool (59-61). The accepted norm is passage of at least $80 \%$ of the 25 radiaopaque markers by day 5 (Figure 1). There is debate as to whether one should suspect anorectal dysfunction if the unpassed markers concentrate in the left colon or rectum (obstructed defecation) (62).

If the transit time is long and the fibre intake is satisfactory, then severe constipation is confirmed (Figure 4). One can then decide whether to go on to more aggressive treatment with polyethylene glycol (PEG), or to test for colon inertia or anorectal dysfunction. If, on the other hand, the transit time is normal, it is difficult to confirm a diagnosis of severe constipation, and none of the above investigations are justified. In such a case, there must be a perception problem requiring patient education or a psychological problem (such as 'denied defecation' $[56,63]$ ) that requires a psychological assessment.

Only a few centres are equipped to carry out sophisticated physiological studies and fewer still have the capability to interpret them correctly; hence, a minority of patients benefit from the results.

Tests for colon inertia: The theoretical importance of discovering colon inertia is that such a patient may benefit from a colon resection. The practical reality is that, in the absence of megacolon, isolated colon inertia is rare. Colon resection will have disastrous results if the patient also has anismus or a neuromuscular disturbance that involves other segments of the gut $(64,65)$. Nevertheless, in certain patients colon 


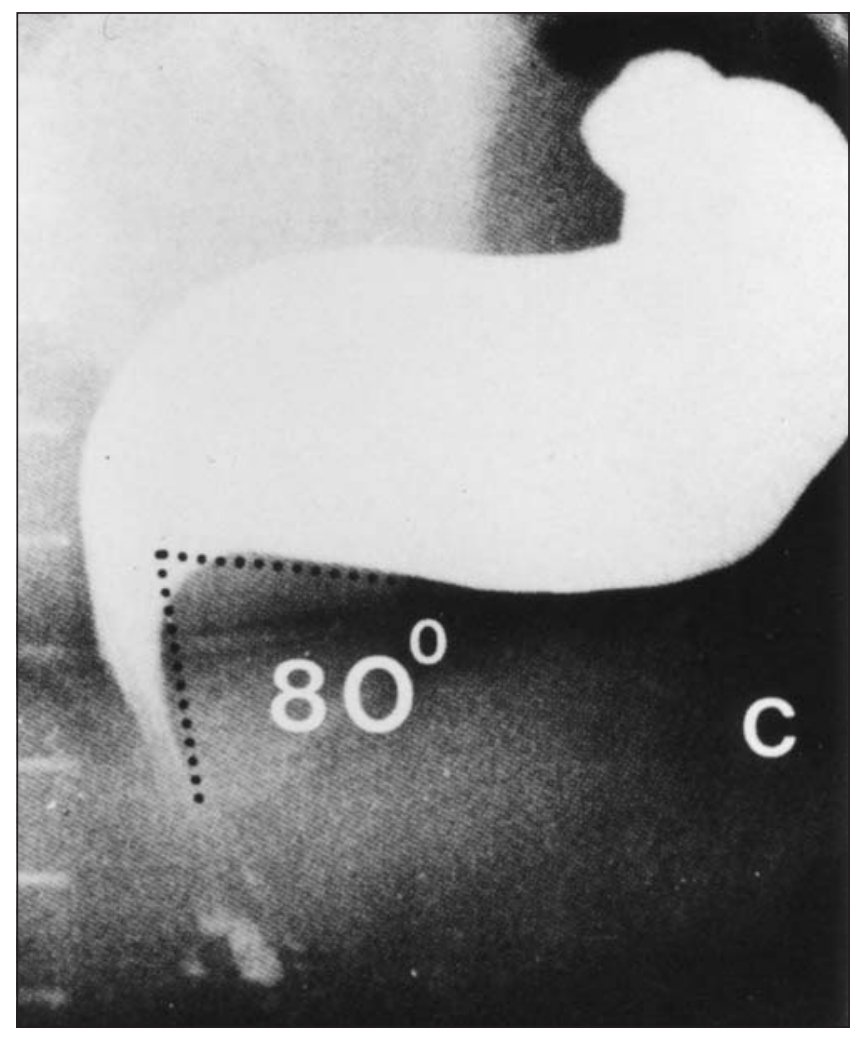

Figure 5) Defecography. Thick barium has been injected into the rectum, demonstrating the anorectal angle held in position by a contracting puborectalis muscle (see Figure 3). This muscle must relax for stool to easily pass. Failure to relax may obstruct defecation

motility can be measured usefully, and there are surgical successes $(66,67)$.

Tests for anorectal dysfunction: Anorectal motility may be measured in a variety of ways, but the most readily available technique is by using a device that measures the internal and external anal sphincter pressure response to intrarectal balloon distension. The most graphic demonstration is through defecography (Figure 5) (45-48). Other techniques include testing the expulsion of plastic stools placed in the rectum (68) and electromyography of the pelvic floor and anal sphincters. Unfortunately, the border between normal and abnormal is indistinct, and surgical management of anorectal dysfunction has been largely unsuccessful. Nevertheless, these tests can: first, detect rectal prolapse or a hitherto unrecognized rectocele; second, if colon resection is contemplated, assure anorectal normalcy; and third, set up the physiological parameters for biofeedback if such treatment is available in the patient's community (69-71). The technical aspects of anorectal assessment and treatments are described elsewhere $(71,72)$.

However, there is still much to learn. Symptoms of pelvic floor dysfunction do not correlate well with physiological tests (73), and no single test can identify whether a patient's constipation is due to IBS, delayed transit or pelvic floor dysfunction (42). While biofeedback is harmless, surgical treatments are not. Other than for Hirschsprung's disease, rectal prolapse or certain rectoceles, anorectal corrective surgery is experi- mental and should not be attempted without advice from centres with sophisticated equipment and expertise.

\section{TREATMENT FOR SEVERE CONSTIPATION}

Laxative measures: Some patients who have troublesome constipation and prolonged transit will have regular defecations when given large doses of an osmotic laxative. PEG is sold as a powder to be mixed in a $4 \mathrm{~L}$ solution as preparation for bowel procedures such as colonoscopy (74). It is available in $1 \mathrm{~L}$ aliquots and can be given in 300 to $400 \mathrm{~mL}$ daily doses $(75,76)$. While PEG does not restore defecation to normal, it does generate regular evacuations, which relieves many patients who have not had regular movements for years. PEG has a low sodium content and is isosmotic with blood; thus, electrolyte abnormalities are unusual if renal and cardiac function are normal. Nonetheless, the monitoring of creatinine and electrolyte levels is wise. In patients in whom no other intervention is likely, this treatment seems to be the best option.

There are reports favouring the use of the gastrokinetic agent cisapride (now withdrawn from the Canadian market) $(77,78)$ and the prostaglandin analogue misoprostyl (79) as treatment for severe constipation, but it is unclear whether those treated in these studies were controlled for fibre intake. While these products cause diarrhea in those who are not constipated, anecdotal and other evidence suggest that they are ineffective in those who are truly constipated (80). Neither drug is without risk, and their chronic use by pregnant (81) or elderly individuals in whom drug interactions are likely is unwise (82).

Many patients select their own laxatives; these may include bisacodyl, anthrocene drugs (senna or cascara) or regular enemas. Sometimes these laxatives are satisfactory and the patient is reluctant to abandon the treatment. However, many gastroenterologists are concerned that these stimulants may, over time, damage the colon (80) and cause electrolyte disturbances $(56,63)$. Soap enemas are potentially dangerous.

Surgical measures: Surgical procedures on the colon and rectum are the province of the few experts and centres that are equipped to handle the selection of suitable patients, as well as the psychological and physiological issues that they present. Surgery should not be performed without expert medical and surgical opinion. Inappropriate colectomy, ileostomy or especially anorectal surgery may leave the patient even more severely disabled.

Other measures: For anismus, some experts recommend biofeedback $(69,71)$. With this technique, technology is employed to train patients with anismus to relax their puborectalis muscle as they try to defecate. Few centres claim success with this technique, which is not easy to apply correctly.

Many patients seek the help of practitioners of alternative medicine or colon laundries. If patients are satisfied with these measures and medical measures have been unsatisfactory, then the physician's duty is confined to ensuring the safety of the treatments being administered. After all, Louis XIV availed himself to daily enemas, and he ruled France for 72 years (56). 


\section{APPENDIX 1 \\ Rome II criteria for constipation \\ In the preceding 12 months, at least 12 weeks (that do not need to be consecutive) having two or more of: \\ - Straining at defecation more than one-quarter of the time \\ - Lumpy or hard stools at defecation more than one-quarter of the time \\ - Sensation of incomplete evacuations more than one-quarter of the time \\ - Sensation of anorectal obstruction or blockage at defecation more than one-quarter of the time \\ - Manual manoeuvres to facilitate defecation more than one-quarter of the time (eg, digital evacuation, support of the pelvic floor) \\ - Less than three defecations per week}

Loose stools should not be present, and there must be insufficient criteria for irritable bowel syndrome. Adapted from references 26 and 27.

\section{REFERENCES}

1. Thompson WG, Heaton KW. Functional bowel disorders in apparently healthy people. Gastroenterology 1980;79:283-8.

2. Probert CS, Emmett PM, Cripps HA, Heaton KW. Evidence for the ambiguity of the term constipation: the role of irritable bowel syndrome. Gut 1994;35:1455-8.

3. Drossman DA, Li Z, Andruzzi E, et al. US householder survey of functional gastrointestinal disorders: Prevalence, sociodemography and health impact. Dig Dis Sci 1993;38:1569-80.

4. Whitehead WE, Winget C, Fedoravicius AS, Wooley S, Blackwell B. Learned illness behavior in patients with irritable bowel syndrome and peptic ulcer. Dig Dis Sci 1982;27:202-8.

5. Heaton KW, Radvan J, Cripps H, Mountford RA, Braddon FE, Hughes AO. Defecation frequency and timing, and stool form in the general population: a prospective study. Gut 1992;33:818-24.

6. Thompson WG, Creed FH, Drossman DA, Heaton KW, Mazzacca G. Functional bowel disorders and functional abdominal pain. Gastroenterol Int 1992;5:75-91.

7. Thompson WG, Creed FH, Drossman DA, et al. Functional bowel disorders and functional abdominal pain. In: Drossman DA, Richter JE, Talley NJ, Thompson WG, Corazziari E, Whitehead WE, eds. The Functional Gastrointestinal Disorders. Boston: Little, Brown \& Company, 1994:115-73.

8. Cummings JH, Hill MJ, Jenkins DJ, Pearson JR, Wiggens HS. Changes in fecal composition and colonic function due to cereal fiber. Am J Clin Nutr 1976;29:1468-73.

9. Stephen A. Constipation. In: Trowell HC, Burkitt DP, Heaton KW, eds. Dietary Fibre, Fibre-depleted Foods and Diseases. London: Academic Press, 1985:133-44.

10. Cummings JH. The effect of dietary fibre on fecal weight and composition. Spiller GA, ed. In: Handbook of Dietary Fiber in Human Nutrition, 1st edn. Boca Raton: CRC Press, 1986:211-80.

11. Strocchi A, Levitt MD. Maintaining intestinal $\mathrm{H}_{2}$ balance; credit the colonic bacteria. Gastroenterology 1992;102:1424-6.

12. Kags TM, Fitzgerald JA, Buckner RY, et al. Influence of methanogenic flora on the breath $\mathrm{H}_{2}$ and symptom response to ingestion of sorbitol or oat fiber. Am J Gastroenterol 1997;92:89-98.

13. Christl SU, Gibson GR, Cummings JH. Role of dietary sulphate in the regulation of methanogenesis in the human large intestine. Gut 1992;33:1234-8.

14. Brodribb AJ, Groves C. Effect of bran particle size on stool weight. Gut 1978;19:60-3.

15. Jenkins DJ, Peterson RD, Thorne MJ, Ferguson PW. Wheat fiber and laxation: dose response and equilibration time. Am J Gastroenterol 1987;82:1259-63.

16. Tucker DM, Sandstead HH, Logan GM Jr, et al. Dietary fiber and personality factors as determinants of stool output. Gastroenterology 1981;81:879-83.

17. Burkitt DP, Walker ARP, Painter NS. Effect of dietary fibre on stools and transit-times, and its role in the causation of disease. Lancet 1972;ii:1408-12.
18. Probert CSJ, Emmett PM, Heaton KW. Some determinants of whole-gut transit time: a population-based study. Q J Med 1995;88:311-5.

19. Probert CSJ, Emmett PM, Cripps HA, Heaton KW. Reality gap - the difference between true and apparent constipation. Gut 1993;33:S69. (Abst)

20. Heaton KW, O’Donnell LJ. An office guide to whole gut transit time. Patient's recollection of their stool form. J Clin Gastroenterol 1994;19:28-30.

21. Lundegardh G, Ekbom A, McLaughlin JK, Nyren O. Gastric cancer risk after vagotomy. Gut 1994;35:946-9.

22. Cummings JH. Diet and transit through the gut. In: Heaton KW, ed. Dietary Fibre: Current Developments of Importance to Health. London: Libbey, 1978:83-95.

23. Spiller GA, Story JA, Wong LG, et al. Effect of increasing levels of hard wheat fiber on fecal weight, minerals and steroids and gastrointestinal transit time in healthy young women. J Nutr 1986;116:778-85.

24. Cummings JH, Bingham SA, Heaton KW, Eastwood MA. Fecal weight, colon cancer risk, and dietary intake of non-starch polysaccharides. Gastroenterology 1992;103:1783-9.

25. Bannister JJ, Davison P, Timms JM, Gibbons C, Read NW. Effect of stool size on defecation. Gut 1987;28:1246-50.

26. Thompson WG, Longstreth GF, Drossman DA, et al. Functional bowel disorders and functional abdominal pain. In: Drossman DA, Corazziari E, Talley NJ, Thompson WG, Whitehead WE, eds. The Functional Gastrointestinal Disorders, 2nd edn. Washington: Degnon, 1999.

27. Thompson WG, Longstreth GF, Drossman DA, Heaton KW, Irvine EJ, Muller-Lissner SA. Functional bowel disorders and functional abdominal pain. Gut 1999;45(Suppl 2):II43-7.

28. Wright SH, Snape WJ Jr, Battle W, Cohen S, London RL. Effect of dietary components on gastrocolonic response. Am J Physiol 1980;238:228-32.

29. Daly J, Bergin A, Sun WM, Read NW. Effect of food and anti-cholinergic drugs on the pattern of rectosigmoid contractions. Gut 1993;34:799-802.

30. Reyburn W. Flushed with Pride: The Story of Thomas Crapper. London: Pavilion Books, 1989.

31. Straining, sitting and squatting at stool. Lancet 1975;ii:18-9.

32. Ogilvie H. The large bowel and its functions. Proc R Soc Med 1951;44:200-6.

33. DiLorenzo C, Dooley CP, Valenzuela JE. Role of fasting gastrointestinal motility in the variability of gastrointestinal transit time assessed by hydrogen breath test. Gut 1991;32:1127-30.

34. Voderholzer WA, Schatke W, Muhldorfer BE, Klauser AG, Birkner B, Muller-Lissner SA. Clinical response to dietary fiber treatment of chronic constipation. Am J Gastroenterol 1997;92:95-8.

35. Kamm MA, Lennard-Jones JE, Thompson DG, Sobnack R, Garvie NW, Granowska M. Dynamic scanning defines a colonic defect in severe idiopathic constipation. Gut 1988;29:1085-92.

36. Preston DM, Lennard-Jones JE. Anismus in chronic constipation. Dig Dis Sci 1985;30:413-8.

37. Sarna SK. Physiology and pathophysiology of colonic motor activity (2). Dig Dis Sci 1991;36:998-1018.

38. Fairgrieve J. Hirschsprung's disease in the adult. BMJ 1962;506-14.

39. Tremaine WJ. Chronic constipation: causes and management. Hosp Pract (Off Ed) 1990;25:89-100.

40. van der Sijp JRM, Kamm MA, Nightingale JMD, et al. Radioisotope determination of regional colonic transit in severe constipation: comparison with radio opaque markers. Gut 1993;34:402-8.

41. Wingate DL. Small bowel manometry. Am J Gastroenterol 1995;90:536-9.

42. Glia A, Lindberg G, Nilsson LH, Mihocsa L, Akerlund JE. Constipation assessed on the basis of colorectal physiology. Scand J Gastroenterol 1998;33:1273-9.

43. Colemont LJ, Camilleri M. Chronic intestinal pseudo-obstruction: diagnosis and treatment. Mayo Clin Proc 1989;64:60-70.

44. Watier A, Devroede G, Duranceau A, et al. Constipation with colonic inertia. A manifestation of systemic disease? Dig Dis Sci 1983;28:1025-33

45. Ekberg O, Mahieu PHG, Bartram CI, Pilloni V. Defecography: dynamic radiologic imaging in proctology. Gastroenterol Int 1990;3:63-9.

46. Wald A, Camara BJ, Freimanis MG, Bauman DH, Hinds JP. 
Contribution of evacuation proctography and anorectal manometry to the evaluation of adults with constipation and defecatory difficulty. Dig Dis Sci 1990;35:481-7.

47. Felt-Bersma RJ, Luth WJ, Janssen JJ, Meuwissen SG. Defecography in patients with anorectal disorders. Which findings are clinically relevant? Dis Colon Rectum 1990;33:277-84.

48. Goei R. Anorectal function in patients with defecation disorders and asymptomatic subjects: evaluation with defecography. Radiology 1990;174:121-3.

49. Cowgill GR, Sullivan AJ. Further studies on the use of wheat bran as a laxative. JAMA 1933;100:795-802.

50. Williams RD, Olmstead WH. The effect of cellulose, hemicellulose and lignin on the weight of the stool: a contribution to the study of laxation in man. J Nutrition 1936;11:433-49.

51. Stephen AM, Wiggins HS, Englyst HN, Cole TJ, Wayman BJ, Cummings JH. The effect of age, sex and levels of intake of dietary fibre from wheat on large-bowel function in thirty healthy subjects. Br J Nutr 1986;56:349-61.

52. Muller-Lissner SA. Effect of wheat bran on weight of stool and gastrointestinal transit time: a meta analysis. Br Med J (Clin Res Ed) 1988;296:615-7.

53. Marlett JA, Li BU, Patrow CJ, Bass P. Comparative laxation of psyllium with and without senna in an ambulatory constipated population. Am J Gastroenterol 1987;82:333-7.

54. Mamtani R, Cimino JA, Cooperman JM, Kugel R. Comparison of total costs of administering calcium polycarbophil and psyllium mucilloid in an institutional setting. Clin Ther 1990;12:22-5.

55. Hamilton JW, Wagner J, Burdick BB, Bass P. Clinical evaluation of methylcellulose as a bulk laxative. Dig Dis Sci 1988;33:993-8.

56. Thompson WG. Gut Reactions: Understanding Symptoms of the Digestive Tract. New York: Plenum Publishing Corporation, 1989.

57. Wessalius-De Casparis A, Braadbaart S, Bergh-Bohlkin GE, Mimica M. Treatment of chronic constipation with lactulose syrup: results of a double-blind study. Gut 1968;9:84-6.

58. Binder HJ, Donowitz M. A new look at laxative action. Gastroenterology 1975;69:1001-5.

59. Evans RC, Kamm MA, Hinton JM, Lennard-Jones JE. The normal range and a simple diagram for recording whole gut transit time. Int J Colorectal Dis 1992; 7:15-7.

60. Metcalf AM, Phillips SF, Zinsmeister AR, MacCarty RL, Beart RW, Wolff BG. Simplified assessment of segmental colonic transit. Gastroenterology 1987;92:40-7.

61. Schindlbeck NE, Klauser AG, Muller-Lissner SA. [Measurement of colon transit time]. Z Gastroenterol 1990;28:399-404.

62. Kuijpers HC. Application of the colorectal laboratory in diagnosis and treatment of functional constipation. Dis Colon Rectum 1990;33:35-9.

63. Thompson WG. Laxative abuse. In: Tytgat GNJ, van Blankenstein M, eds. Current Topics in Gastroenterology and Hepatology. New York: Springer-Verlag, 1990:236-45.
64. Vasilevsky A, Nemer FD, Balcos EG, Christenson CE, Goldberg SM. Is subtotal colectomy a viable option in the management of chronic constipation? Dis Colon Rectum 1988;31:679-81.

65. Kamm MA, Hawley PR, Lennard-Jones JE. Outcome of colectomy for severe idiopathic constipation. Gut 1988;29:969-73.

66. Leon SH, Krishnamurthy S, Schuffler MD. Subtotal colectomy for severe idiopathic constipation. A follow-up study of 13 patients. Dig Dis Sci 1987;32:1249-54.

67. Gasslander T, Larsson J, Wetterfors J. Experience of surgical treatment for chronic idiopathic constipation. Acta Chir Scand 1987;153:553-5.

68. Barnes PR, Lennard-Jones JE. Balloon expulsion from the rectum in constipation of different types. Gut 1985;26:1049-52.

69. Anismus and biofeedback. Lancet 1992;339:217-8.

70. Bleijenberg G, Kuijpers HC. Biofeedback treatment of constipation: a comparison of two methods. Am J Gastroenterol 1994;89:1021-6.

71. Whitehead WE. Biofeedback treatment of gastrointestinal disorders. Biofeedback Self Regul 1992;17:59-76.

72. Whitehead WE, Chaussade S, Corazziari E, Kumar D. Report of an international workshop on management of constipation. Gastroenterol Int 1991;4:99-113.

73. Mertz H, Naliboff B, Mayer EA. Symptoms and physiology in severe chronic constipation. Am J Gastroenterol 1999;94:131-8.

74. Ernstoff JJ, Howard DA, Marshall JB. A randomized blinded clinical trial of a rapid colonic lavage solution (Golytely) compared with standard preparation for colonoscopy and barium enema. Gastroenterology 1983;84:1512-6.

75. Klauser AG, Muhldorfer BE, Voderholzer WA, Wenzel G, Muller-Lissner SA. Polyethylene glycol 4000 for slow transit constipation. Z Gastroenterol 1995;33:5-8.

76. Andorsky RI, Goldner F. Colonic lavage solution (polyethylene glycol electrolyte lavage solution) as a treatment for chronic constipation: a double-blind, placebo-controlled study. Am J Gastroenterol 1990;85:261-5.

77. Schuurkes J. Prokinetic substituted benzamides: in vitro studies and their mechanism of action. In: Kamm MA, Lennard-Jones JE, eds. Gastrointestinal Transit: Physiology and Pharmacology. Bristol: Wright Biomedical, 1991.

78. Chokhavatia S, Phipps T, Anuras S. Comparative laxation of calcium polycarbophil with psyllium mucilloid in an ambulatory geriatric population. Curr Ther Res Clin Exp 1988;44:1013-9.

79. Soffer EE, Metcalf A, Launspach J. Misoprostol is effective treatment for patients with chronic constipation. Dig Dis Sci 1994;39:929-33

80. Muller-Lissner SA. Adverse effects of laxatives: facts and fiction. Pharmacology 1993;47(Suppl 1):138-45.

81. Fennerty MB. Is a pound of prevention worth an ounce of cure? Gastroenterology 1996;110:958-60.

82. Wysowski DK, Bacsanyi J. Cisapride and fatal arrythmia. N Engl J Med 1996;335:290-1. 


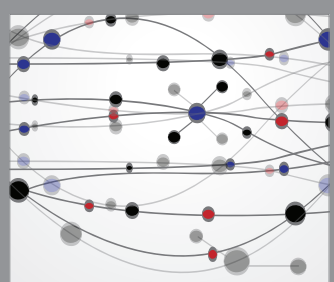

The Scientific World Journal
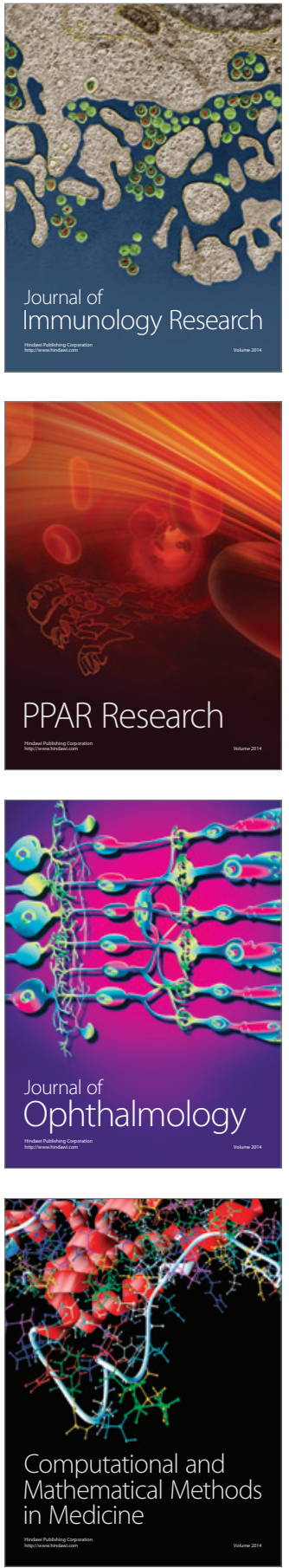

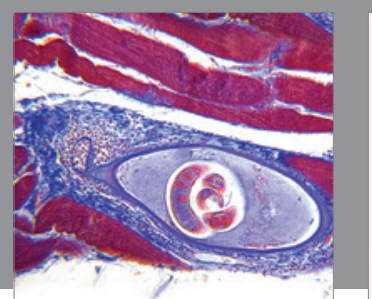

Gastroenterology Research and Practice

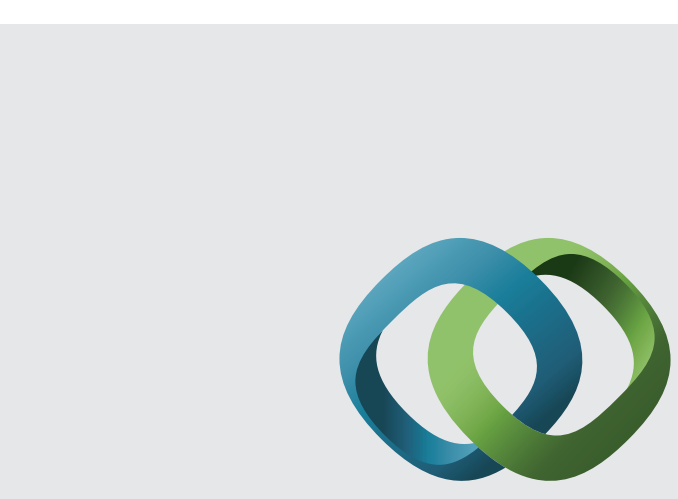

\section{Hindawi}

Submit your manuscripts at

http://www.hindawi.com
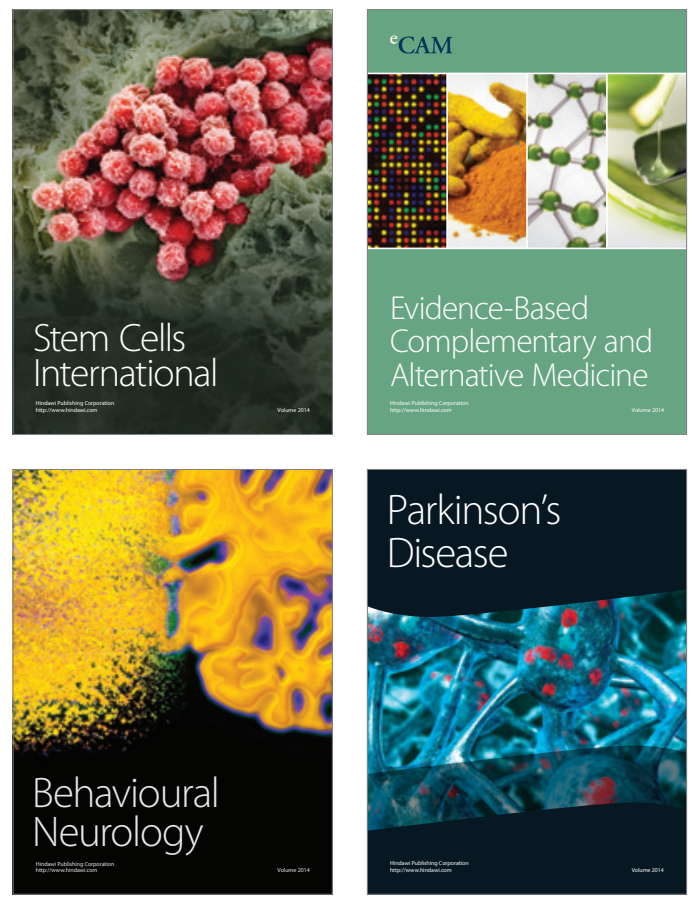
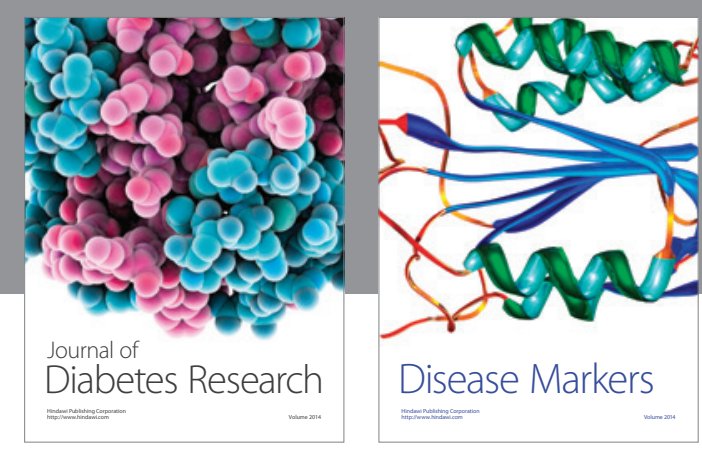

Disease Markers
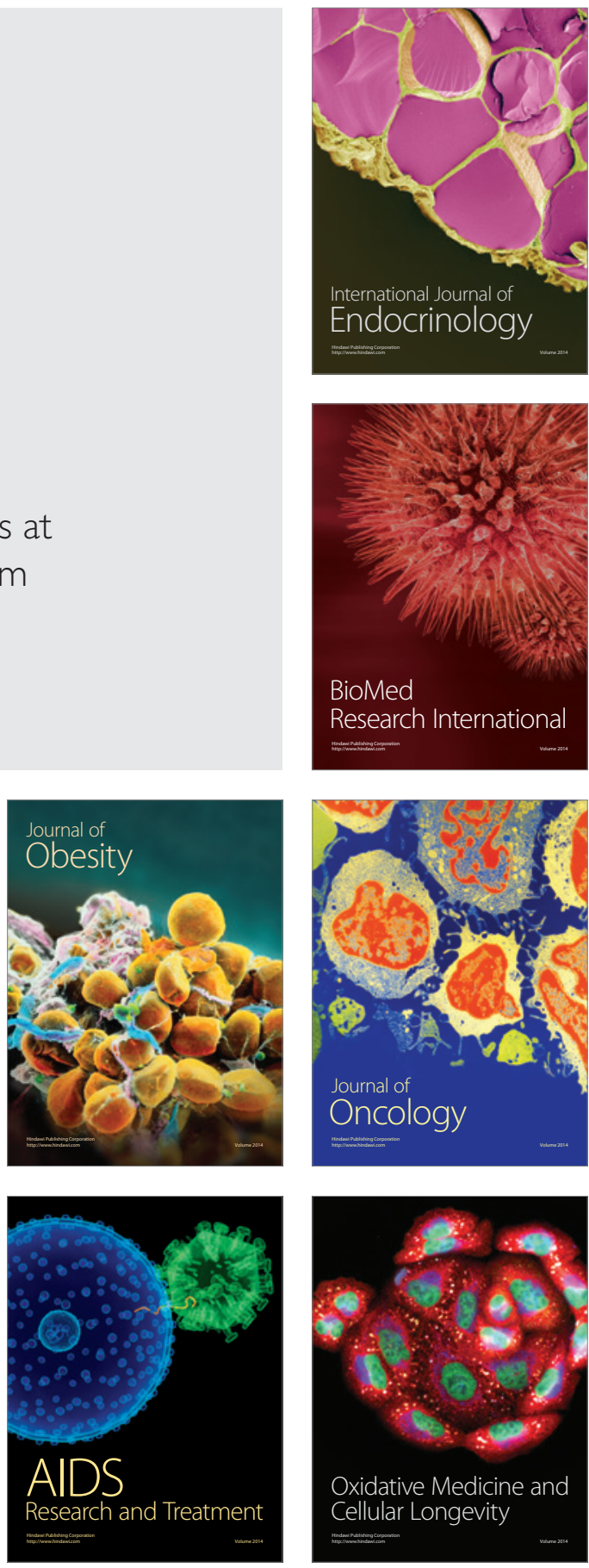